IRA-International Journal of Applied Sciences

ISSN 2455-4499; Vol.03, Issue 03 (2016)

Institute of Research Advances

http://research-advances.org/index.php/IRAJAS

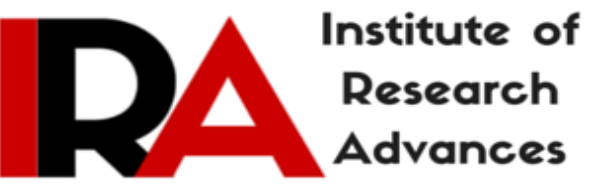

\title{
A case of fever and rash; Dilemma of MRSA versus Kawasaki disease
}

Doaa Youssef

Assistant Professor of Pediatrics

Zagazig University, Zagazig, Egypt.

DOI: http://dx.doi.org/10.21013/jas.v3.n3.p2

\section{How to cite this paper:}

Youssef, D. (2016). A case of fever and rash; Dilemma of MRSA versus Kawasaki

disease. IRA-International Journal of Applied Sciences (ISSN 2455-4499), 3(3).

doi:http://dx.doi.org/10.21013/jas.v3.n3.p2

(C) Institute of Research Advances

(cc) EY-NC

This works is licensed under a Creative Commons Attribution-Non Commercial 4.0 International License subject to proper citation to the publication source of the work.

Disclaimer: The scholarly papers as reviewed and published by the Institute of Research Advances (IRA) are the views and opinions of their respective authors and are not the views or opinions of the IRA. The IRA disclaims of any harm or loss caused due to the published content to any party. 


\section{ABSTRACT}

Kawasaki disease $(K D)$ is an acute febrile systemic vasculitis that was first described by Kawasaki et.al in 1974. [1]. KD is regarded as an autoimmune disorder rather than an infectious disease. [2]. in the USA, where community acquired methicilline resistant staph (CA-MRSA) is now the most common pathogen (>50\%) causing skin and soft tissue infections (particularly abscesses) acquired by outpatients, the number of these infections has nearly doubled in six years, and the main burden of MRSA infections, measured as the incidence per 100000 inhabitants, now falls on the general population [3]. We present here a case report of a girl came with fever and rash and it had criteria of both diseases KD and CA-MRSA.

Keywords: Kawasaki, MRSA, rash, children

\section{Case report:}

Female patient 11 years old presented to us in Kids hospital, Cairo, with fever and pharngitis 4 days not responding to amoxicillin- clavulenic antibiotic and antipyretics; her lab was done on 2nd day and they were negative as regards CRP, CBC.

On 4th day; Skin rash started to appear on trunk (Figure 1), face, palm, ears, back and buttock, bilateral conjunctivitis with sub-conjunctival hemorrhage (Figure 2). Admitted to hospital for investigation

CRP was 405/8, CBC WITH TLC 7000 with $97.3 \%$ neutrophils, platelet 138, while waiting blood culture and viral serological and autoimmune markers to appear We started imipenem, vancomycine.

Next day $5^{\text {th }}$ day; CRP rose to $495 / 8$ and all immunological markers were negative as regard ANA, C3, ANCA, anti Double stranded DNA, Rheumatoid factor, Free Kidney function test, Liver function test, Urine analysis, free echocardiography apart from slight rigt ventericle dilatation

At that level we suspected Kawasaki diseases; thus we started IVIG $2 \mathrm{gm}$ per $\mathrm{kg}$ divided on 5 days for feasibility of administration and acetyl salicylic acid for two weeks.

Rash disappeared, fever decreased gradual and stooped on day 8 i.e $3^{\text {rd }}$ day of IVIG administration, CRP goes down gradually daily up to $10 / 8$ on $10^{\text {th }}$ day but Platelets rose gradual to 965 on $10^{\text {th }}$ day

The surprising event on this day we received the result of blood culture which was positive for MRSA.

The case was discharged on day 11 with follow up of clinical and CBC, CRP titer for the next three weeks, the condition was stable with no recurrence of fever or any other symptoms, the follow up echo on the $2^{\text {nd }}$ week was free and there were no pealing up to 4 th week 


\section{Discussion:}

Our case had criteria of both diseases KD and MRSA as; it could be MRSA with rash and high CRP and initial total leukocyte count shift and low platelet, and it could be Kawasaki with pharyngitis, high fever for more 5 days, bilateral conjunctivitis, skin rash and raised platelet from day 7 to $10^{\text {th }}$ day and gradual decrease to normal after 2 weeks.

The diagnosis of $\mathrm{KD}$ is not sharp and determined in our case as to date, there is no specific diagnostic test for KD. Diagnosis is based on the presence of fever lasting longer than 5 days and four of five specific clinical criteria. In Japan, at least five of six criteria (fever and five other clinical criteria) should be fulfilled for a diagnosis of KD. However, patients with four of the principal clinical features can be diagnosed when coronary aneurysm or dilatation is recognized [4]

The result of blood culture was a little odd as our case was not admitted to hospital before this illness but; Hospitals and nursing homes were once the main reservoirs of MRSA, but new ones have now emerged outside of the healthcare setting. [5]

\section{References:}

1-Kawasaki T, Kosaki F, Okawa S, Shigematsu I, Yanagawa H. A new infantile acute febrile mucocutaneous lymph node syndrome (MLNS) prevailing in Japan. Pediatrics 1974;54: 271e6.

2- Shimizu C, Jain S, Davila S, et al. Transforming growth factorbeta signaling pathway in patients with Kawasaki disease. Circ Cardiovasc Genet 2011;4:16e25.

3- David MZ, Daum RS: Community-associated methicillin-resistant Staphylococcus aureus: epidemiology and clinical consequences of an emerging epidemic. Clin Microbiol Rev 2010; 23: 616-87.

4-Kuo HC, Wang CL, Wang L, Yu HR, Yang KD. Patient characteristics and intravenous immunoglobulin product may affect eosinophils in Kawasaki disease. Pediatr Allergy Immunol 2008; 19:184e5

5-Köck R, Mellmann A, Schaumburg F, Friedrich AW, Kipp F, Becker K. The epidemiology of methicillin-resistant Staphylococcus aureus (MRSA) in Germany. Dtsch Arztebl Int. 2011 Nov;108(45):761-7. doi: 10.3238/arztebl.2011.0761. Epub 2011 Nov 4. 


\section{Figure legend:}

Figure 1: rash on trunk on $4^{\text {th }}$ day of fever

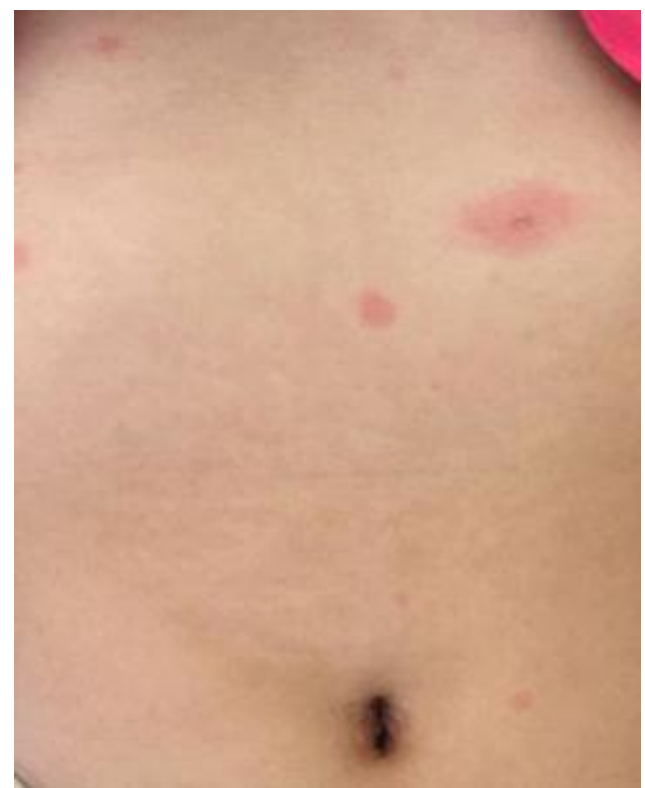

Figure 1

Figure 2: bilateral conjunctivitis with sub-conjunctival hemorrhage on $4^{\text {th }}$ day of fever

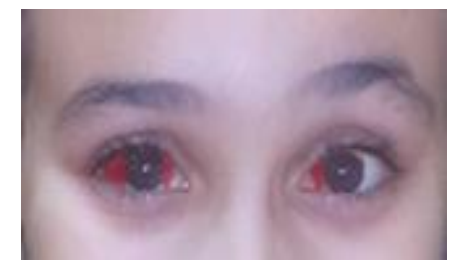

Figure 2 